\title{
How long to be negative? Prolonged viral shedding and the implications on service provision in Cardiac Surgery
}

\author{
Dharsicka Nadarajah ${ }^{1}$, Sundeep Kaul ${ }^{1}$, Anne Hall ${ }^{1}$, Paras Dalal $^{1}$, and Jaymin Morjaria ${ }^{1}$ \\ ${ }^{1}$ Royal Brompton and Harefield NHS Trust
}

June 3, 2020

\begin{abstract}
Severe acute respiratory syndrome coronavirus 2 (SARS-CoV-2), which originated in China, is the cause of the global pandemic Coronavirus Disease 19 (Covid-19). To date, there is no widely available vaccine or treatment, hence containment strategies are currently centred around measures ameliorating human transmission via social distancing and quarantine. Due to the magnitude of the pandemic, elective operative work had been halted within cardiac surgery at our institution and protocols adapted to facilitate safe operating and discharge of surgical patients. With rapidly emerging data on the characteristics of SARS-CoV-2, we present 2 in-patient cases at our institution with prolonged viral shedding detected on real-time polymerase chain reaction (RT-PCR) oropharyngeal swabs; one asymptomatic, and another pauci-symptomatic. These cases highlight the need for further research into the duration of viral shedding and the viability of SARS-CoV-2, especially with respect to viral transmission, over a drawn-out period.
\end{abstract}

\section{Hosted file}

Coronavirus Case Report 03062020 DN - Journal of Cardiac Surgery submission 2.0.pdf available at https://authorea.com/users/329287/articles/456303-how-long-to-be-negativeprolonged-viral-shedding-and-the-implications-on-service-provision-in-cardiac-surgery 


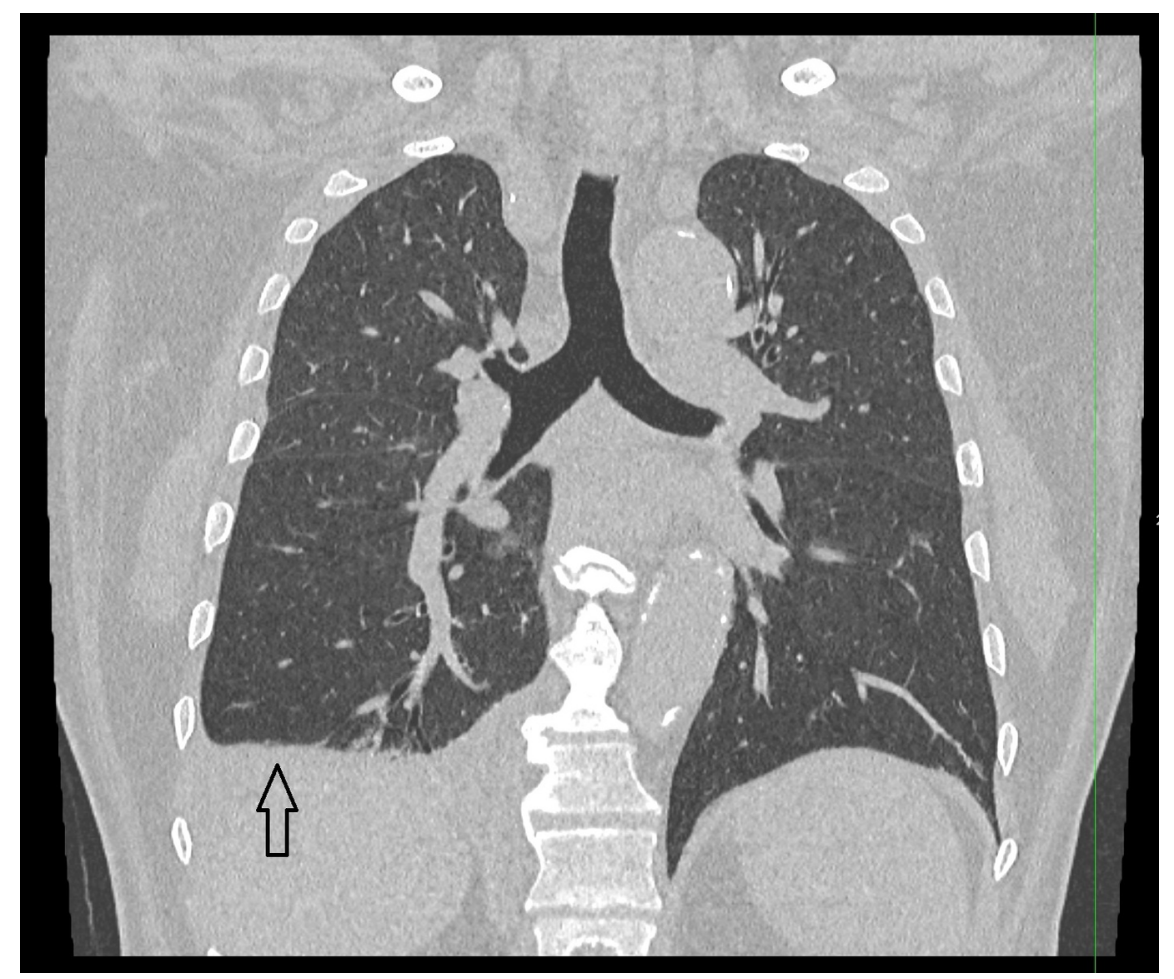




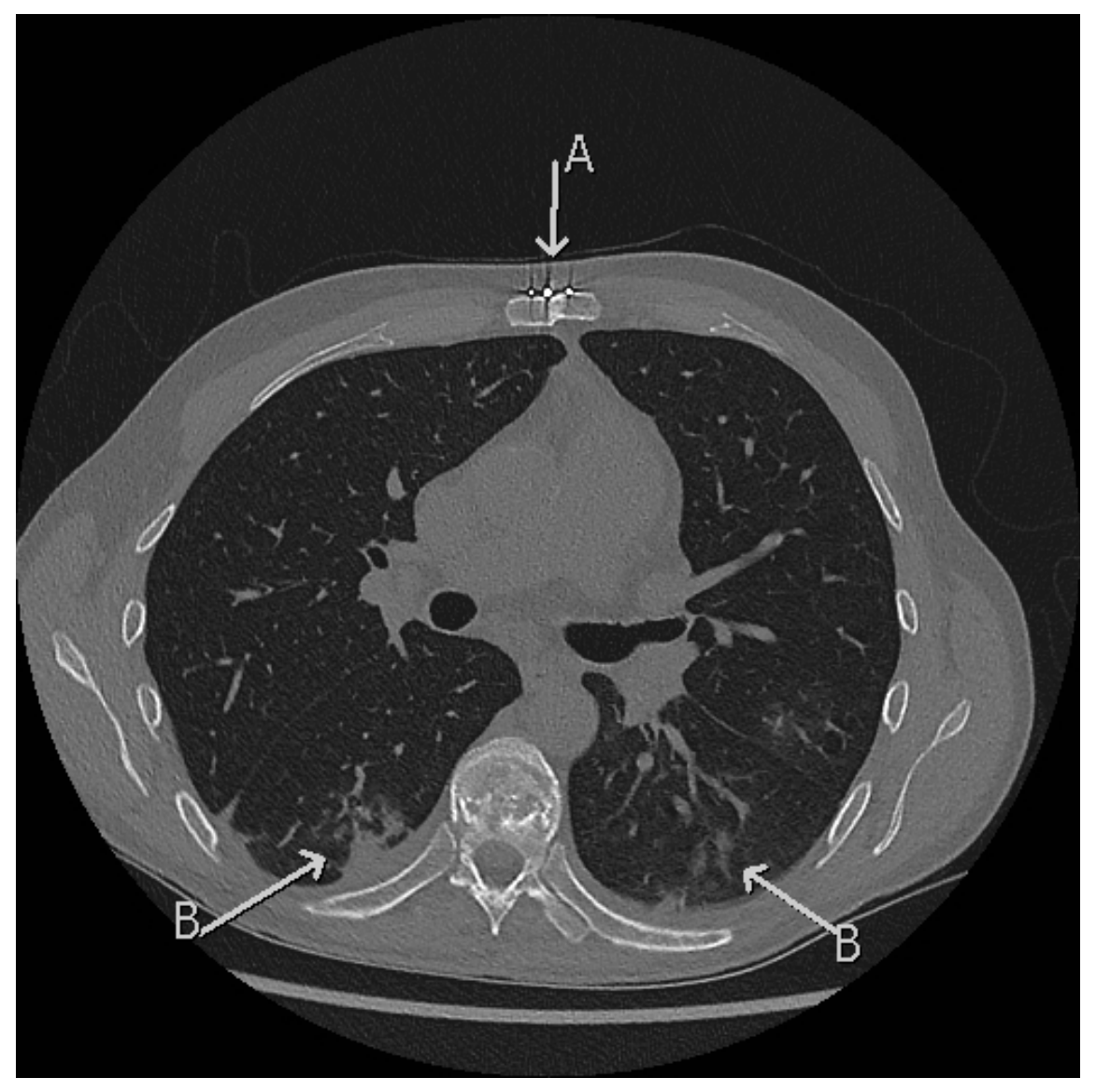

\section{Hosted file}

Table 1.docx available at https://authorea.com/users/329287/articles/456303-how-long-to-benegative-prolonged-viral-shedding-and-the-implications-on-service-provision-in-cardiacsurgery 